\title{
BIAS GENDER DALAM VERBA: Sebuah Kajian Leksikon dalam Bahasa Inggris
}

\author{
Sri Isnani Setiyaningsih \\ Universitas Islam Negeri (UIN) Walisongo Semarang \\ e-mail: thahar_nusha@yahoo.com
}

\begin{abstract}
Abstrak
Kajian gender merupakan analisis yang digunakan dalam menempatkan posisi setara antara laki-laki dan perempuan untuk mewujudkan tatanan masyarakat sosial yang lebih egaliter. Tulisan ini akan membahas bias gender dari sisi bahasa, karena bahasa telah mewakili sistem kehidupan masyarakat. Kemungkinan besar setiap bahasa mempunyai sisi-sisi bias gender, tidak terkecuali bahasa Inggris, dimana jenis masyarakat dalam kenyataan hidup lebih diwakili oleh kaum laki-laki dan perempuan. Bias gender pada bahasa ini lebih difokuskan pada ranah verba (kata kerja/yang menunjukan aktivitas) dalam sistem leksikon dengan melihat bagaimana struktur kosakata bahasa Inggris ${ }^{1}$ tersusun dalam mensimbolkan keberadaan dua jenis kelamin dan hubungan keduanya. Bias gender pada kategori ini dapat dilihat dalam empat bentuk, yaitu (1) aktivitas yang secara tradisional dianggap layak dilakukan oleh gender tertentu, (2) aktivitas yang secara tradisional biasa dilakukan oleh gender tertentu, (3) aktivitas yang memang dilakukan gender tertentu demi gender lain, dan (4) aktivitas yang secara kodrati hanya bisa dilakukan gender tertentu
\end{abstract}

\footnotetext{
1Sebenarnya, bahasa Inggris tergolong rumpun bahasa Jermanik, khususnya cabang Jermanik Barat. Kerabat terdekatnya adalah bahasa Friesland. Selain itu bahasa Belanda (termasuk pula bahasa-bahasa Jerman hilir lainnya) juga masih dekat. Bahasa Jerman (Bahasa Jerman hulu) agak lebih jauh lagi. Tetapi dari semua bahasa Jermanik, bahasa Inggris adalah bahasa yang paling lain secara tatabahasa dan kosakata. Kosakata bahasa Inggris banyak dipengaruhi oleh bahasa Perancis, yang masuk melalui penaklukan bangsa Norman yang memungkinkan penggunaan bahasa Perancis sebagai bahasa resmi selama beberapa abad di lingkungan pemerintahan. Dari seluruh kosakata bahasa Inggris modern, diperkirakan $\pm 50 \%$ berasal dari bahasa Perancis dan Latin (sebagai bahasa Induk dari bahasa Perancis). Saat ini, status bahasa bahasa Inggris adalah bahasa pertama di Amerika Serikat, Antigua dan Barbuda, Australia, Bahama, Barbados, Bermuda, Britania Raya, Guyana, Jamaika, Saint Kitts dan Nevis, Selandia Baru dan Trinidad dan Tobago. Selain itu bahasa Inggris juga merupakan salah satu bahasa resmi di organisasi internasional seperti Perserikatan Bangsa-Bangsa dan Komite Olimpiade Internasional, serta bahasa resmi di berbagai negara, seperti di Afrika Selatan, Belize, Filipina, Hong Kong, Irlandia, Kanada, Nigeria, Singapura, dan lainnya.
} 
dan aktivitas yang mendeskreditkan atau bermakna negatif pada gender tertentu.

Kata Kunci: bias; gender; leksikon; verba bahasa Inggris

\section{A. Pendahuluan}

Sebenarnya bahasa merupakan ekspresi seseorang untuk mewakili logika, struktur budaya, sosial, psikologi, filosofi, dan politik yang dianut oleh penuturnya ${ }^{2}$ meskipun si penuturnya sering tidak memperhatikan apa yang dikomunikasikan baik lewat isyarat, simbol maupun lisan. Oleh karena itu, bahasa bukan sekedar simbol yang dapat dipahami oleh komunitas tertentu, akan tetapi mempunyai ruang lingkup yang luas termasuk struktur strata masyarakat yang dibentuk oleh kebiasaan, norma, etika, adatistiadat, nilai-nilai universal kemanusiaan, agama dan lain-lain.

Di antara struktur strata masyarakat yang dibentuk oleh kebiasaan adalah masalah gender yang kadang-kadang disalahartikan orang sebagai bentuk jenis kelamin tertentu (baca perempuan), ${ }^{3}$ karena seringnya istilah ini melekat pada gerakan feminisme atau gerakan emansipasi wanita. Secara umum gender ini dapat diasumsikan kepada kelompok laki-laki ataupun perempuan, karena gender ini netral tergantung penggunaan pemaknaannya. Biasanya salah satu pihak (laki-laki atau perempuan) merasa hak-haknya terpinggirkan sementara kewajibannya adalah sama atau tidak ada perbedaan antara laki-laki dan perempuan, maka pihak yang merasa terpinggirkan, yang biasanya adalah kaum wanita, mengklaim bahwa dirinya terkena perlakuan bias gender, baik perlakuan itu merupakan kebijakan politik, pendidikan, interaksi sosial maupun dalam segi ungkapan bahasa. Secara jelas Zaitunah Subhan mengemukakan bahwa yang dimaksud gender adalah konsep analisis yang dipergunakan untuk menjelaskan sesuatu yang didasarkan pada pembedaan laki-laki dan perempuan karena konstruksi sosial budaya. ${ }^{4}$ Pengertian yang lebih konkret dan lebih operasional dikemukakan

2De Saussure, Course in General Linguistics, (London: Cambrige, 2000), h. 20.

${ }^{3}$ Jenis kelamin secara kodrati adalah the given dari Allah, namun gender merupakan bentukan masyarakat karena perebutan kepentingan maupun win-win solution dalam situasi yang sulit untuk dicarikan jalan keluar. Lihat Aryani, Pengarusutamaan Gender dalam Kurikulum IAIN, (Yogyakarta: PSW-IAIN Press, 2004), h. 7.

"Subhan, "Gender dalam Perspektif Islam", dalam Jurnal Akademika, Vol. 06, No. 2, Maret, h. 128. 
oleh Nasaruddin Umar bahwa gender adalah konsep kultural yang digunakan untuk memberi identifikasi perbedaan dalam hal peran, perilaku dan lain-lain antara laki-laki dan perempuan yang berkembang di dalam masyarakat yang didasarkan pada rekayasa sosial. ${ }^{5}$

Kajian ini akan membahas bias gender dari sisi bahasa, karena bahasa telah mewakili sistem kehidupan masyarakat. Kemungkinan besar setiap bahasa mempunyai sisi-sisi bias gender, tidak terkecuali bahasa Inggris, karena jenis masyarakat dalam kenyataan hidup lebih diwakili oleh kaum laki-laki dan perempuan. Hubungan laki-laki dan perempuan dalam struktur masyarakat, meskipun saling membutuhkan, kadang-kadang juga saling memperebutkan posisi dalam bidang politik, seni budaya, ekonomi, dan sosial, sehingga terbentuk apa yang disebut dengan istilah bias gender. Kajian ini penting dalam kaitannya dengan isu keadilan yang secara distributif memiliki tiga prinsip utama yaitu kesetaraan, persamaan, dan kebutuhan. Dengan kata lain, manusia berhak diberi ganjaran atas usaha dan produktivitasnya, dihukum atas pelanggaran yang dilakukannya, diperlakukan sebagai manusia secara setara, dan terpenuhi kebutuhan dasarnya tidak peduli apapun jenis kelaminnya. ${ }^{6}$

Selama ini banyak penelitian atau karya ilmiah tentang bias gender yang dialamatkan kepada kelompok agama tertentu, seperti struktur masyarakat muslim yang sering dituduh dipengaruhi oleh ajaran yang bias gender di mana hak-hak wanita selalu dipinggirkan, atau bias gender dalam bahasa $\mathrm{Arab}^{7}$ serta model-model pendidikan di dunia Timur, termasuk dunia Islam. Sebenarnya, kedudukan manusia dalam Islam adalah setara di hadapan Tuhan dan hanya dibedakan berdasarkan kualitas amal perbuatannya. Dengan demikian, menilai Islam, dengan mengkaji bahasa Arab misalnya, sebagai ajaran yang bias gender hanya karena bahasa Arab memang milik komunitas yang sangat patriarkal adalah tidak adil. Itu artinya memunculkan penilaian terhadap sebuah konsep nilai ideal dengan realitas aplikasinya

\footnotetext{
${ }^{5}$ Nasaruddin Umar, "Perspektif Gender dalam Islam", Jurnal Paramadina, Vol. I. No. 1, Juli-Desember 1998, h. 99.

${ }^{6}$ Maiese, "Principles of Justice and Fairness." http://www.beyondintractability.org/biessay/principles-of-justice (diunduh 17 November 2014).

${ }^{7}$ Seperti kata syaqilah yang berarti wanita pelacur, qazirah artinya perempuan kotor dan lain-lain. Baca Gunawan, 'Leksikon Bias Gender Bahasa Arab' dalam Jurnal Adabiyyat, vol. 4, 2005.
} 
dalam kehidupan manusia, yang sebenarnya berbeda. Islam sendiri mengajarkan keadilan dengan konsep menempatkan sesuatu pada tempatnya. ${ }^{8}$

Sementara itu, kajian-kajian bias gender yang dialamatkan kepada kebudayaan Barat termasuk bahasa Inggris dalam dunia Timur masih jarang, padahal sebetulnya bahasa-bahasa tersebut juga mengandung banyak bias gender dalam pemakaian sehari-hari, baik sebagai sebutan jabatan, sebutan wanita nakal, wanita kurang pintar, kurang terampil dan lain-lain. Contoh kecil misalnya kata chairman. Kata ini menggunakan bentuk maskulin, padahal kata ini juga digunakan untuk perempuan yang menyandang posisi sebagai ketua. Kalau dicari bentuk femininnya tentu ada istilah chairwoman. ${ }^{9}$ Ada kemungkinan dicarikan jalan keluar dengan istilah chairperson, tetapi kata ini tidak lazim digunakan dalam pergaulan sehari-hari. Bila dirunut dalam kebudayaan Barat, laki-laki mendapatkan porsi lebih kuat termasuk sebagai pemimpin dalm persindangan, pengambil keputusan, pendamai dan lain-lain, maka sang pemimpin ini disebut chairman.

Kecilnya kajian budaya Barat termasuk bahasa Inggris dalam masyarakat Timur mungkin disebabkan oleh beberapa hal, seperti inferioritas Timur sebagai a low tradition nation, yang menganggap Barat sebagai a high tradition nation yang selalu memberi inspirasi perubahan-perubahan persamaan hak antara laki-laki dan perempuan dalam politik, budaya dan lainlain.

Dengan berbekal hipotesis Sapir-Whorf (teori relativitas bahasa) yang menyatakan bahwa bahasa mempengaruhi budaya, dan oleh karenanya, untuk melihat apa yang terjadi pada sebuah budaya, kita dapat melihatnya dari struktur bahasanya (baik struktur bentuk juga makna). Inilah yang menjadi alasan untuk mengkaji bias gender dalam leksikon bahasa Inggris dan bagaimana pengaruh keberadaan elemen leksikal bias gender tersebut pada penutur bahasa yang bersangkutan. Dalam hal ini akan dideteksi seluruh elemen leksikal yang mengandung pembedaan jenis kelamin dalam komponen semantiknya sebagai potensi elemen leksikal bias gender untuk

\footnotetext{
${ }^{8}$ Baca al-Qadhi Abd al-Jabbar, Ushul al-Khamsah, Juz 2, (al-Qahirah: Dar al-Kutub alArabiyah, 1324H), h. 432.

${ }^{9}$ Baca Makalah Pengukuhan Guru Besar Mukminatien, "Hubungan antara Bahasa dan Gender serta Implikasinya dalam Pembelajaran Writing," 6 Mei 2010 di Universitas Negeri Malang.
} 
kemudian diidentifikasi apakah elemen tersebut menunjukkan pola bias tertentu dalam penggunaannya sehingga dapat disimpulkan tentang kondisi budaya masyarakat penggunanya.

Bias gender dalam bahasa Inggris tentu akan berimplikasi bagi penggunanya baik secara psikologis maupun sosiologis. Implikasi ini akan memberikan gerak terbatas kepada pihak yang merasa dirugikan hak-haknya. Apabila bias gender dalam leksikon bahasa Inggris ini terkuak lebih jelas, maka para pengkaji bahasa Inggris dapat lebih memahami struktur budaya Barat secara umum (Inggris Raya, Amerika Serikat, Canada, Australia, New Zealand, dan lain-lain) dengan memahami bagaimana gender diposisikan oleh masyarakat berbahasa Inggris itu. Oleh karena itu, tulisan ini akan memfokuskan diri pada akar bagaimana bias gender dalam bentuk verba tercermin dalam leksikon bahasa Inggris?"

\section{B. Bias Gender dalam Leksikon Bahasa Inggris}

Kajian gender merupakan analisis yang digunakan dalam menempatkan posisi setara antara laki-laki dan perempuan untuk mewujudkan tatanan masyarakat sosial yang lebih egaliter. Jadi, gender bisa dikategorikan sebagai perangkat operasional dalam melakukan measurement (pengukuran) terhadap persoalan laki-laki dan perempuan terutama yang terkait dengan pembagian peran dalam masyarakat yang dikonstruksi oleh masyarakat itu sendiri. Gender bukan hanya ditujukan kepada perempuan semata, tetapi juga kepada laki-laki. Hanya saja, yang dianggap mengalami posisi termarginalkan sekarang adalah pihak perempuan, maka perempuanlah yang lebih ditonjolkan dalam pembahasan untuk mengejar kesetaraan gender yang telah diraih oleh laki-laki beberapa tingkat dalam peran sosial, terutama di bidang pendidikan karena bidang inilah yang diharapkan dapat mendorong perubahan kerangka berpikir, bertindak, dan berperan dalam berbagai segmen kehidupan sosial.

Konsep gender berbeda dari seks atau jenis kelamin (laki-laki dan perempuan) yang bersifat biologis, walaupun dalam pembicaraan seharihari seks dan gender dapat saling dipertukarkan. Sebenarnya ilmu bahasa (linguistik) juga menggunakan istilah gender (alternatif lain adalah genus) bagi pengelompokan kata benda (nomina) dalam sejumlah bahasa. Banyak bahasa, yang terkenal dari rumpun bahasa Indo-Eropa (contohnya bahasa Spanyol) dan Afroasiatik (seperti bahasa Arab), mengenal kata benda mas- 
kulin dan feminin (beberapa juga mengenal kata benda netral). Akan tetapi, konsep gender di sini adalah peran gender individu di masyarakat, sehingga orang mengenal maskulinitas dan femininitas. Namun demikian, sesuatu yang dianggap maskulin dalam satu kebudayaan bisa dianggap sebagai feminin dalam budaya lain. Dengan kata lain, ciri maskulin atau feminin itu tergantung pada konteks sosial budaya bukan semata-mata pada perbedaan jenis kelamin.

\section{Bias Gender dalam Bahasa}

Kata bias dalam istilah bias gender berasal dari bahasa Inggris dengan arti "often supporting or opposing a particular person or thing in an unfair way by allowing personal opinions to influence your judgment10" atau pemihakan terhadap suatu pihak secara tidak adil. Jadi pengertian bias dapat terjadi karena faktor-faktor yang ada pada diri pengamat itu sendiri. Usaha untuk mencegah terjadinya bias dapat dilakukan dengan latihan pada mereka yang akan bertindak..$^{11}$

Bias gender adalah pembagian posisi dan peran yang tidak adil antara laki-laki dan perempuan. Perempuan dengan sifat feminin dipandang selayaknya berperan di sektor domestik, sebaliknya laki-laki yang maskulin sudah sepatutnya berperan di sektor publik. Seperti kasus adanya perusahaan-perusahaan yang masih "menganakemaskan" kaum pria dan menutup peluang bagi kesetaraan perempuan dalam hal gaji, penugasan, dan promosi, seperti kasus Citigroup yang akhirnya digugat oleh enam eksekutif perempuan.

Jika sebuah bahasa dikatakan bias gender, itu berarti bahwa bahasa tersebut memihak salah satu gender tertentu dengan satu dan lain cara. Hal ini biasanya muncul dalam bentuk adanya kecenderungan orientasi laki-laki, mempertahankan diskriminasi yang tidak adil, dan mendorong pada sikap merendahkan peran wanita dalam masyarakat. ${ }^{12}$ Kajian bias gender secara linguistik ini muncul sejak berkembangnya gerakan kesetaraan gender. Dikatakan bahwa terdapat dua wilayah sistem linguistik yang mungkin bias

${ }^{10}$ Electronic Cambridge Advanced Learner's Dictionary (CALD). $3^{\text {rd }}$ Ed.

${ }^{11}$ Ensiklopedi Nasional Indonesia, Cet. III, h. 351.

${ }^{12}$ Crystal, The Cambridge Encylopedia of Language, (Birmingham: Cambrige University Press, 1989), h. 46. 
gender, yaitu tata bahasa dan kosakata (atau leksikon). Dalam kasus pemakaian bahasa Inggris, ketiadaan bentuk orang ketiga tunggal yang netral sering memunculkan masalah dalam pembentukan struktur tata bahasa. Dalam kosakata, hal ini terjadi misalnya adalah kecenderungan penggunaan bentuk gender tertentu untuk merujuk pada genus umum.

Kajian ini akan melihat bias gender dalam sistem leksikon dengan melihat bagaimana struktur kosakata bahasa Inggris $^{13}$ tersusun dalam mensimbolkan keberadaan dua jenis kelamin dan hubungan keduanya.

\section{Struktur Leksikon Bahasa}

Istilah leksikon (lexicon) secara umum berarti daftar seluruh kata yang digunakan dalam sebuah bahasa, suatu subjek, atau sebuah kamus. ${ }^{14}$ Dalam definisi itu ditulis "seluruh kata". Istilah "kata" dalam linguistik untuk mengacu pada struktur semantik sebuah bahasa dianggap kurang pas. Hal ini mengingat istilah "kata" tidak hanya bermakna satu unit semantik. Istilah "kata" dapat saja berarti unit semantik yaitu unit abstrak yang merupakan sebuah kelompok bentuk dengan makna yang sama, tetapi "kata" dapat pula mengacu pada satu bentuk bebas konkrit yang dipakai dalam konstruksi tata bahasa. Leech ${ }^{15}$ mengartikan istilah leksikon sebagai seluruh elemen atau unit leksikal suatu bahasa yang dapat terdiri dari kata atau idiom. Unit leksikal ini merupakan kombinasi tiga macam deskripsi,

\footnotetext{
${ }^{13}$ Sebenarnya, bahasa Inggris tergolong rumpun bahasa Jermanik, khususnya cabang Jermanik Barat. Kerabat terdekatnya adalah bahasa Friesland. Selain itu bahasa Belanda (termasuk pula bahasa-bahasa Jerman hilir lainnya) juga masih dekat. Bahasa Jerman (Bahasa Jerman hulu) agak lebih jauh lagi. Tetapi dari semua bahasa Jermanik, bahasa Inggris adalah bahasa yang paling lain secara tatabahasa dan kosakata. Kosakata bahasa Inggris banyak dipengaruhi oleh bahasa Perancis, yang masuk melalui penaklukan bangsa Norman yang memungkinkan penggunaan bahasa Perancis sebagai bahasa resmi selama beberapa abad di lingkungan pemerintahan. Dari seluruh kosakata bahasa Inggris modern, diperkirakan $\pm 50 \%$ berasal dari bahasa Perancis dan Latin (sebagai bahasa Induk dari bahasa Perancis). Saat ini, status bahasa bahasa Inggris adalah bahasa pertama di Amerika Serikat, Antigua dan Barbuda, Australia, Bahama, Barbados, Bermuda, Britania Raya, Guyana, Jamaika, Saint Kitts dan Nevis, Selandia Baru dan Trinidad dan Tobago. Selain itu bahasa Inggris juga merupakan salah satu bahasa resmi di organisasi internasional seperti Perserikatan Bangsa-Bangsa dan Komite Olimpiade Internasional, serta bahasa resmi di berbagai negara, seperti di Afrika Selatan, Belize, Filipina, Hong Kong, Irlandia, Kanada, Nigeria, Singapura, dan lainnya.

${ }^{14}$ Electronic CALD.

${ }^{15}$ Leech, Semantics, (New Rochdale: University Press, 1998), h. 206.
} 
yaitu deskripsi morfologis, sintaksis, dan semantik. Deskripsi morfologis membagi kata dalam morfem-morfem (sekaligus dengan informasi tentang bunyi dan ejaannya). Deskripsi sintaksis berisi seperangkat fitur yang mengelompokan kata berdasarkan distribusinya dalam kalimat sebagai kategori kelas kata dan subkategorinya. Deskripsi semantik berisi fitur-fitur semantik sebuah kata yang dapat dipaparkan dalam bentuk fitur-fitur kontrastif (seperti +insani; +dewasa; +pria) atau dengan serangkaian simbol yang merepresentasikan argument-argumen dan predikatnya.

Adapun mengenai struktur leksikon/kosakata, Ulmann ${ }^{16}$ mensarikan adanya tiga tingkatan dalam menemukan bagaimana kosakata dirganisir dalam sebuah bahasa atau dengan kata lain bagaimana stuktur kosakata dapat dijelaskan. Ketiga tingkatan itu adalah tingkatan (1) kata per kata, (2) lingkup konseptual, dan (3) kosakata secara keseluruhan. Dalam tingkatan pertama teorinya adalah teori Associative Field 'medan asosiatif yang diperkenalkan oleh Bally. ${ }^{17}$ Teori ini beranggapan bahwa tiap kata dikelilingi oleh jaringan asosiasi yang didasarkan kepada hubungan makna (semantik), hubungan bentuk (morfologi), dan hubungan makna dan bentuk (sintaktik). Hubungan jaringan tersebut dapat berdasarkan kesamaan, kedekatan (antar makna, antar nama, dan antar makna dan nama). Teori yang melandasi tingkatan kedua adalah teori medan semantik dari Trier yang menyatakan bahwa sistem semantik bahasa dapat dijelaskan dengan memfokuskan diri pada bidang kehidupan tertentu yang direalisasikan oleh seperangkat unsur leksikal yang maknanya berhubungan. ${ }^{18}$ Tingkatan yang ketiga, yaitu struktur umum kosakata, menurut Ulmann dapat didekati dengan kajian statistik atau kajian linguistik murni. Secara statistik, struktur kosakata ini disusun dan dijelaskan melalui teori informasi yang dibantu komputerisasi dan memang dapat membantu menjelaskan berbagai hal dalam semantik. Pendekatan linguistik murni, di sisi lain, berusaha menemukan sistem rasional tentang konsep-konsep dan mengembangkan tipologi semantik. ${ }^{19}$

\footnotetext{
16Ulmann, Semantics: An Introduction to the Science of Meaning, (Philadelpia: Pitts University. 1999), h. 238.

${ }^{17}$ Ibid., h. 238-243.

${ }^{18}$ Ibid., h. .243-253.

${ }^{19}$ Ibid., h. 253-258.
} 
Dalam kupasan leksikon bias gender ini, dari ketiga tingkatan itu, hanya tingkatan kedua yang digunakan sebagai alat untuk membedah data. Tingkatan pertama yang hanya menjelaskan hubungan satu kata dengan kata lain tidak sesuai dengan pola masif data. Tingkatan ketiga tidak akan digunakan karena kajian ini akan lebih bersifat kualitatif (bukan statistik), dan tidak akan membahas keseluruhan konsep yang ada dalam kosakata atau membandingkan berbagai sistem konseptual bahasa.

\section{Bias Gender pada Verba Bahasa Inggris}

Verba adalah seluruh yang menunjukan aksi (perbuatan, tindakan, proses, gerak), kondisi (keadaan) dan pengalaman (terjadinya sesuatu). Verba merupakan kelas kata yang biasanya berfungsi sebagai predikat. Beberapa bahasa verba mempunyai ciri morfologis seperti kata, aspek, dan pesona atau jumlah. Hal ini menunjukan bahwa verba merupakan satu kategori kata yang memegang peranan penting dalam proses (keaktifan) berbahasa. Penampakan atau rupa satuan fungsi atau satuan gramatikal verba dapat berbentuk monomorfemis (kata tunggal) dan polimorfemis (kata kompleks), serta verba dasar/pangkal/asal dan turunan.

Bias gender tampak pada kategori ini dalam empat bentuk: aktivitas yang secara tradisional dianggap layak dilakukan oleh gender tertentu, aktivitas yang secara tradisional biasa dilakukan oleh gender tertentu, aktivitas yang memang dilakukan gender tertentu demi gender lain, aktivitas yang secara kodrati hanya bisa dilakukan gender tertentu dan aktivitas yang mendeskreditkan atau bermakna negatif pada gender tertentu.

\section{a. Aktivitas yang Secara Tradisional Dianggap Layak Dilakukan oleh Gender Tertentu}

Aktivitas yang secara tradisional yang dianggap layak dilakukan oleh gender tertentu maksudnya adalah aktivitas yang dianggap layak dilakukan oleh laki-laki maupun perempuan. Aktivitas tersebut tercermin dalam berbagai jenis verba, salah satunya adalah verba tindakan (action verb). Verba tindakan (action verb) banyak digunakan di berbagai buku teks berbahasa Inggris yang kemudian dicross check ke dalam kamus Cambridge Advance Learner's Dictionary (CALD). Kategori verba tindakan yang telah ditemukan adalah verba yang menunjukan gerak/aktivitas nyata (activity verb), verba 
yang menunjukan proses (process verb), verba yang menunjukan indera tubuh (verb of bodily sensation), verba yang menunjukan aktivitas peristiwa penting (momentary verb) dan verba yang menunjukan kejadian/peristiwa transisi (transitional event verb).

Pertama, aktivitas yang tercermin dalam verba yang menunjukan gerak/ aktivitas nyata (activity verb) dimana aktivitas tesebut lebih memihak kepada laki-laki. Sebagai contoh verba gave, said, told, to know, to look, own, came, dan to go. Verba tersebut menunjukan aktivitas yang memiliki gerak cekatan, dan keinginan yang kuat untuk melakukannya. Verba dengan karakteristik ini lebih didominasi pada jenis laki-laki. Sementara verba dengan karakteristik gerakan yang lembut dan feminin dihubungkan dengan tingkah laku perempuan, misalnya to care, to giggle, to think, wanted, to make, to keep, to show, to buy, dan to get. ${ }^{20}$ Contoh kalimat yang menunjukan activity verb yang dianggap layak melakukannya adalah perempuan:

In the library, Fatimah giggles inapproprietly. (Di dalam perpustakaan, Fatimah terkekeh-kekeh dengan wajar)

To giggle merupakan verba gerak karena ini adalah sesuatu gerak yang menunjukan Fatimah yang melakukannya. To giggle yang berarti tertawa terkekeh-kekeh atau tertawa genit merupakan suatu gerakan atau aktivitas yang memiliki karakteristik fiminin.

Kedua, verba yang menunjukan proses kegiatan (process verb) lazim digunakan bentuk verba continuous/progressive (sedang berlangsung). Verba proses yang lebih berpihak pada laki-laki adalah accepting, accommodating, accumulating, accompanying, achieving, acting, adapting, playing, training dan meeting. Proses aktivitas dalam di atas lebih dominan dilakukan oleh lakilaki. Sementara verba yang menunjukan proses aktivitas yang berhubungan dengan perempuan adalah talking, discussing, working, driving, giving, waiting, asking, cleaning dan learning. ${ }^{21}$ Aktivitas proses playing dan meeting, lebih didominasi oleh kegiatan pihak laki-laki, sementara mengobrol/berbicara banyak (talking) dan membersihkan sesuatu (cleaning) lebih berhubungan dengan aktivitas yang layak dilakukan perempuan.

\footnotetext{
${ }^{20}$ Didukung oleh penelitian Sydney, Gameliel Valentino Mkucu, "Gender Roles in Textbook as Function of Hidden Curriculum in Tanzania Primary School."

${ }^{21}$ Didukung oleh penelitian Cooke-Sawyer,S., "Gender Bias and Sex Role Stereorypes in Grade Seven History Textbooks."
} 
Ketiga, aktivitas inderawi yang tercermin dalam verb of bodily sensation. Aktivitas ini dilakukan oleh indera tubuh manusia yang berhubungan dengan aktivitas laki-laki yaitu, believe, rage, volunteered, forget, admire, annoyed, mature, dan pity. Sementara itu, verb of bodily sensation yang berhubungan dengan aktivitas inderawi perempuan, yaitu suffer, confuse, fail, doubt, hug, cry, react, dan sense.22

Keempat, momentary verb yaitu verba yang menunjukan aktivitas kejadian atau hal-hal yang sangat penting untuk diingat. Aktivitas tersebut yang dihubungkan dengan laki-laki adalah found, decided, looked, heard, won, arrested, admitted, chose dan spent. Sementara itu, aktivitas yang dihubungkan dengan perempuan tercermin dalam verba join, married, paid, caught, promised, suggest, helped, visited, dan saved. ${ }^{23}$

Kelima, verba yang menunjukan peristiwa/kejadian peralihan tercermin dalam transitional event verb. Aktivitas dalam verba tersebut yang bisa dihubungkan dengan laki-laki adalah asked, failed, tried, moved, continued, finished, warned dan turned. ${ }^{24}$ Peristiwa peralihan merupakan kejadian antara aktivitas pertama dengan selanjutnya, sebagai contoh kata moved (pindah) merupakan kejadian peralihan dari aktivitas diam ke aktivitas bergerak ke suatu tempat. Aktivitas ini digambarkan dengan suatu tindakan yang memiliki keberanian, arogansi, optimis dan percaya diri. Sebaliknya, gambaran yang melekat pada aktivitas perempuan menunjukan aktivitas tersebut membutuhkan kesabaran, perhatian dan kelembutan. Verba yang tercermin dalam aktivitas yang menunjukan karakteristik tersebut adalah passed, lose, arrived, noticed, shouted, overcaome, discovered, waited, dan changed.

Berikut ini tabel aktivitas yang layak dilakukan oleh gender tertentu yang tercermin dalam verba gerak (action verb). Nigeria".

${ }^{22}$ Didukung oleh penelitian Baraimah, C., "An Analysis of English Textbooks in

${ }^{23}$ Didukung oleh beberapa penelitian, diantaranya Ryf, J. "English Language Textbooks in Zimbabwe: A Gender Analysis. Lihat juga Liew Peok Chong. An analysys of Gender and Ethnic Representations in Chinese and Malay Primary School Reading Textbooks Grade 2-6". dan Mazile P., "The Portrayal of Women in Botswana's Social Studies and History Textbooks."

${ }^{24}$ Didukung oleh penelitian Liew Peok Chong. "An Analysys of Gender and Ethnic Representations in ...." 
Tabel Action Verb Bias Gender

\begin{tabular}{|l|l|l|}
\hline \multicolumn{1}{|c|}{ Action Verb } & \multicolumn{1}{c|}{ Laki-laki } & \multicolumn{1}{c|}{ Perempuan } \\
\hline $\begin{array}{l}\text { Verba yang menunjukan } \\
\text { aktivitas fisik (activity verb) }\end{array}$ & $\begin{array}{l}\text { gave, said, told, to know, to } \\
\text { look, own, came, dan to go }\end{array}$ & $\begin{array}{l}\text { to care, to giggle, to } \\
\text { think, wanted, to make, } \\
\text { to keep, to show, to buy, } \\
\text { dan to get }\end{array}$ \\
\hline $\begin{array}{l}\text { Verba yang menunjukan } \\
\text { proses kegiatan (process verb) }\end{array}$ & $\begin{array}{l}\text { accepting, accommodating, } \\
\text { accumulating, accompanying, } \\
\text { achieving, acting, adapting, } \\
\text { playing, training dan meeting }\end{array}$ & $\begin{array}{l}\text { talking, discussing, } \\
\text { working, driving, giving, } \\
\text { waiting, asking, cleaning } \\
\text { dan learning }\end{array}$ \\
\hline $\begin{array}{l}\text { Verba yang menunjukan pada } \\
\text { indera tubuh (bodily sensation } \\
\text { verb) }\end{array}$ & $\begin{array}{l}\text { believe, rage, volunteered, } \\
\text { forget, admire, annoyed, } \\
\text { mature, dan pity. }\end{array}$ & $\begin{array}{l}\text { suffer, confuse, fail, } \\
\text { doubt, hugs, cry, react, } \\
\text { dan sense }\end{array}$ \\
\hline $\begin{array}{l}\text { Verba yang menunjukan } \\
\text { peristiwa/kejadian penting } \\
\text { (momentary verb) }\end{array}$ & $\begin{array}{l}\text { found, decided, looked, } \\
\text { heard, won, arrested, } \\
\text { admitted, chose dan spent }\end{array}$ & $\begin{array}{l}\text { join, married, paid, } \\
\text { caught, promised, } \\
\text { suggest, helped,visited, } \\
\text { dan saved }\end{array}$ \\
\hline $\begin{array}{l}\text { Verba yang menunjukan } \\
\text { kejadian peralihan } \\
\text { (transitional event verb) }\end{array}$ & $\begin{array}{l}\text { asked, failed, tried, moved, } \\
\text { continued, finished, warned } \\
\text { dan turned }\end{array}$ & $\begin{array}{l}\text { passed, lose, arrived, } \\
\text { noticed, shouted, } \\
\text { overcaome, discovered, } \\
\text { waited, dan changed }\end{array}$ \\
\hline
\end{tabular}

Selain penjelasan mengenai bias gender pada verba gerak (action verb) di atas, ada beberapa aktivitas yang secara tradisional pelaku dianggap layak melakukannya. Artinya, meskipun aktivitas tersebut bisa dilakukan oleh kedua belah pihak (laki-laki dan perempuan), namun salah satu pihak lebih mendominasi dalam kegiatan tersebut. Sebagai contoh, aktivitas yang secara tradisional yang dianggap layak dilakukan oleh laki-laki, baik untuk memulai aktivitas maupun dalam prosesnya yang ditunjukan dengan sikap keaktifannya, yaitu hubungan seksual. Hubungan seksual artinya secara prinsip adalah tindakan sanggama yang dilakukan oleh manusia. Akan tetapi dalam arti yang lebih luas juga merujuk pada tindakan-tindakan lain yang sehubungan atau menggantikan tindakan sanggama, jadi lebih dari sekedar merujuk pada pertemuan antar alat kelamin laki-laki dan perempuan. Secara sosial budaya, hubungan seksual mempunyai variasi cara dan tradisi. Laki-laki menunjukkan minat seksual yang lebih kuat daripada perempuan, walaupun baik laki-laki maupun perempuan menunjukkan keinginan yang sama untuk keterlibatan dalam berhubungan seksual. 
Sehingga untuk memulai hubungan tersebut, laki-laki lebih memiliki inisiatif mengajak atau memulainya. Misalnya dengan rayuan, bercumbu dan sebagainya. Beberapa verba yang menunjukan tentang hubungan seksual, yaitu to be intimate, to make out, to have a go at it, to get it on, to do it, to screw, to fuck, to jazz, to eff, to hump, to bang, to bed, to bonk, to copulate, dan to deflower.

Sebagai contoh pada frasa verba have a go at it. Makna to have a go at it adalah to have sex (melakukan hubungan seksual/bersetubuh). Kegiatan hubungan seksual to have a go at it, berbeda dengan to love. Have a go at it memiliki karakteristik sebuah hubungan seksual dimana laki-laki lebih mendominasi aktivitasnya, artinya kegiatan ini memihak pada laki-laki, sedangkan to love merupakan hubungan seksual yang bisa didominasi kedua belah pihak (netral) baik laki-laki ataupun perempuan .

Secara linguistik, verba to have a go at it dapat diklasifikasikan berdasar sinonim, hipernim, hiponim dan kelompok verba. Sinonim merupakan kata yang memiliki bentuk yang berbeda namun memiliki arti atau pengertian yang sama atau mirip. Verba yang memiliki arti yang sama atau bersinggungan dengan to have a go at it yang bermakna melakukan hubungan seksual (have sexual intercourse with) adalah to bang, to be intimate, to bed, bonk, do it, to eff, to fuck, to get it on, to get laid, to have intercourse, to have it away, to have it off, to have sex, to hump, to jazz, to know, to lie with, to love, to make love, to make out, to roll in the hay, to screw, to sleep together, dan to sleep with. Namun dari beberapa verba di atas yang lebih dominan pada keaktifan laki-laki yang memulai ataupun melakukannya adalah to be intimate, to make out, to have a go at it, to get it on, to do it, to screw, to fuck, to jazz, to eff, to hump, to bang, to bed, to bonk, to copulate, dan to deflower. Adapun daftar verba tersebut dapat dikategorikan sebagai berikut:

Tabel Daftar Verba

\begin{tabular}{|l|l|l|l|}
\hline \multicolumn{1}{|c|}{ Item } & \multicolumn{1}{|c|}{ Kategori } & \multicolumn{1}{c|}{ Bias Gender } & \multicolumn{1}{c|}{ Pola } \\
\hline sleep together & phrase & netral & netral \\
\hline roll in the hay & phrase & netral & netral \\
\hline make out & phrase & bias & male is active \\
\hline make love & phrase & netral & netral \\
\hline sleep with & phrase & netral & netral \\
\hline
\end{tabular}




\begin{tabular}{|c|c|c|c|}
\hline Item & Kategori & Bias Gender & Pola \\
\hline get laid & phrase & netral & netral \\
\hline have sex & phrase & netral & netral \\
\hline be intimate & phrase & bias & male is active \\
\hline have intercourse & phrase & netral & netral \\
\hline have it away & phrase & netral & netral \\
\hline have it off & phrase & netral & netral \\
\hline have a go at it & phrase & bias & male is active \\
\hline get it on & phrase & bias & male is active \\
\hline lie with & phrase & netral & netral \\
\hline do it & phrase & bias & male is active \\
\hline know & verb & netral & netral \\
\hline love & verb & netral & netral \\
\hline Screw & verb & bias & male is active \\
\hline fuck & verb & bias & male is active \\
\hline jaz & verb & bias & male is active \\
\hline eff & verb & bias & male is active \\
\hline Hump & verb & bias & male is active \\
\hline bang & verb & bias & male is active \\
\hline bed & verb & bias & male is active \\
\hline bonk & verb & bias & male is active \\
\hline copulate & verb & bias & male is active \\
\hline mate & verb & netral & netral \\
\hline pair & verb & netral & netral \\
\hline couple & verb & netral & netral \\
\hline deflower & verb & bias & male is active \\
\hline
\end{tabular}

Hipernim adalah kata yang cakupan maknanya luas/ kata-kata yang mewakili kata lain. Hipernim untuk verba yang bersinggungan dengan to have a go at it yang bermakna mempunyai ikatan hubungan seksual (engage in sexual intercourse) adalah: to copulate, to couple, to mate, dan to pair. Secara 
umum, laki-laki lebih memiliki peran yang kuat dalam sebuah hubungan seksual. Peran ini menjadikan perempuan lebih terikat dalam hubungannya. Sebagai contoh dalam hubungan seksual (bersetubuh) laki-laki lebih aktif dari pada perempuan untuk memulai atau melakukan hubungan tersebut.

Sementara itu, hiponim adalah bagian dari hipernim yaitu item yang mewakili keseluruhan. Hiponim untuk verba yang bersinggungan dengan to have a go at it adalah to have dan to take (melakukan hubungan seksual), ini merupakan istilah lama yang digunakan untuk merujuk pada makna berhubungan seksual, serta to fornicate (melakukan hubungan seksual tanpa menikah terlebih dahulu). Kata to have and to take di atas memiliki kecenderungan laki-laki yang lebih aktif mengajak atau beraktivitas dalam kegiatan seksual. Sementara itu, kata to fornicate merupakan hubungan seksual namun bermakna negatif, karena dilakukan oleh pasangan (laki-laki atau perempuan) yang tidak mempunyai ikatan pernikahan, dalam agama Islam kegiatan seksual tanpa ada ikatan perkawinan dinamakan berzina.

Selanjutnya, kelompok verba dari to have a go at it adalah to make out, dan to neck (merupakan kelompok kata kerja yang bersinggungan dengan to kiss, to embrace, or to fondle with sexual passion). Kata to make out dan to neck merupakan bentuk aktivitas seksual dimana laki-laki lebih dominan atau aktif dalam kegiatan tersebut. Keaktifan laki-laki ditunjukan dengan ciuman (to kiss), pelukan (to embrace) atau usapan dengan hastrat seksual (to fondle with sexual passion).

Selain verba to have a go at it, verba to deflower merupakan bentuk kata yang merujuk pada kegiatan yang memang hanya dilakukan oleh laki-laki. Kata to deflower, secara konotasi memiliki arti memetik bunga, sementara makna sebenarnya adalah merenggut kegadisan atau keperawanan. Kata ini memiliki makna kegiatan yang mengacu pada nomina defloration yaitu pemetikan bunga (kegadisan/keperawanan). Gadis atau perawan adalah merujuk istilah seorang perempuan yang belum pernah melakukan kegiatan seks sebelumnya. Pada kata to deflower tersirat kegiatan yang lebih aktif dilakukan oleh laki-laki, sementara perempuan sebagai objek atau pihak yang dikenai perbuatan tersebut. Kata deflower yang penggunaannya lebih khusus pada aktivitas laki-laki. Sebagai contoh:

1) She was deflowered by a man who worked in the factory. (Dia dperkosa oleh laki-laki yang bekerja di perusahaan itu) 
2) This dirty old man deflowered several young girls in the village. (Laki-laki tua yang lusuh itu menggagahi beberapa gadis di desa tersebut)

Verba lain adalah verba dalam bentuk frasa (verbal phrase) tentang hubungan 'berkencan' yaitu to ask sb out. Frasa to ask sb out merupakan frasa verba yang bermakna meminta seseorang keluar, mengandung pengertian mengundang seseorang untuk datang dengan Anda ke tempat seperti bioskop atau restoran, terutama sebagai cara untuk memulai hubungan yang romantis. To ask sb out merupakan frasa yang dalam penggunaan bias, sebagaimana dalam kamus (FD). Secara umum penggunaan frasa ini lebih cenderung digunakan oleh laki-laki, karena tradisi 'mengajak seseorang yang lawan jenis untuk keluar rumah' lebih didominasi pada laki-laki daripada perempuan. Contoh kalimat dari frasa to ask sb out.

"I hate when people say that." No he figures he'll ask out the next girl when he's more 'nature' in two years.

Kata yang sepadan dengan frasa ask sb out adalah kata date. Kata date sebagai verba memiliki beberapa arti:

1) Kencan - pergi berkencan sebagai contoh kalimat "Tonight she is dating a former high school sweetheart".

2) Pergi keluar - meninggalkan rumah untuk pergi kemana saja. Contoh pada kalimat, "We never date when our children were small". Kata date maknanya sama dengan went out.

3) Kencan ganda - pergi keluar untuk kencan dengan pasangannya dan pasangan yang lain. Contoh pada kalimat, "let's double date this Saturday".

Selain to ask sb out, kata to date lebih merujuk pada aktivitas laki-laki dan perempuan yang melakukan pertemuan di suatu tempat. Meskipun kata ini bisa digunakan untuk perempuan, tetapi kebiasaan yang lebih aktif memulai kegiatan tersebut adalah laki-laki. Aktivitas date biasanya dilakukan jika pihak laki-laki menawarkannya pada pihak perempuan. Jarang pelaksanaan date terjadi manakala yang memulai atau menawarkan terlebih dahulu adalah pihak perempuan, meskipun di sebagian negara aktivitas date bisa dimulai dari pihak perempuan.

Aktivitas date (berkencan) dilihat dari budaya sangat berbeda di setiap daerah atau negara. Sebagai contoh, di Amerika Serikat, meskipun sopan 
bagi laki-laki menawarkan diri untuk membayar tagihan (bill) atau mentraktir makan malam (dinner), ketentuan umum sebagai kebiasaan adalah siapa yang mengajak kencan adalah biasanya orang yang membayar bill. Di Kanada dan Belanda, kebiasaan tersebut berbeda. Lebih umum bagi pasangan untuk membagi tagihan (bill) dan membayar masing-masing. Dalam budaya Latin, biasanya laki-laki membayar apa pun untuk perempuan. Perbedaan lainnya termasuk di mana pasangan boleh pergi kencan, dan boleh kencan asal didampingi anggota keluarga perempuan. Aktivitas date menjadi bias sebagi contoh, di Amerika Serikat, laki-laki biasanya menahan pintu dan menarik kursi untuk pasangan kecannya. Namun, di Swedia, lakilaki tidak melakukan ini karena memegang pintu dipandang sebagai menghina perempuan sebagai indikasi bahwa dia lemah.

Makna to ask sb out hampir mirip dengan makna kata to date yang artinya berkencan. Meskipun keduanya melakukan aktivitas yang sama (berkencan), namun keduanya memiliki perbedaan. Istilah to ask sb out lebih mengarah pada aktivitas yang layaknya dilakukan oleh laki-laki terhadap perempuan sementara kata to date bersifat netral, artinya meskipun lazimnya kencan dimulai dari ajakan laki-laki, namun penggunaan date bisa berarti perempuan yang mengajak laki-laki atau keduanya sama-sama mengajak berkencan.

Masih terkait dengan aktivitas yang layak dilakukan oleh gender tertentu, yaitu verba tentang hubungan 'melamar', contohnya to betroth, to propose marriage, to ask to marry, dan to court. Verba to betroth, to propose marriage, dan to ask to marry mempunyai arti melamar atau bertunangan. Sementara itu, makna to court mempunyai arti mengajak seseorang menjalin hubungan dengan seseorang dengan harapan bisa menikah. Makna tersebut sama maksudnya dengan melamar. Kata court bersinonim dengan kelompok verba to woo, to romance, dan to solicit.

Dalam banyak kasus budaya istilah meminang atau melamar itu datangnya dari laki-laki. Hal ini bukan hanya diwakili oleh budaya-budaya masyarakat tertentu, seperti budaya Timur, Islam, Barat dan lain-lain. Padahal kalau melihat arti kata tersebut sebetulnya melamar untuk mengikat sebuah perkawinan datangnya boleh dari pihak laki-laki maupun perempuan. Terkait dengan penggunaan kata di atas, seluruh kamus bahasa membedakan antara kata-kata melamar dan menikah, adat/kebiasaan juga 
membedakan antara laki-laki yang sudah meminang (bertunangan) dengan yang sudah menikah; dan di dalam hukum pun membedakan secara jelas antara kedua istilah tersebut. Melamar tidak lebih dari sekedar mengumumkan keinginan untuk menikah dengan perempuan tertentu, sedangkan pernikahan merupakan aqad yang mengikat dan perjanjian yang kuat yang mempunyai batas-batas, syarat-syarat, hak-hak, dan akibat-akibat tertentu. Oleh karena itu, melamar merupakan kegiatan yang lebih menitik beratkan pada aktivitas laki-laki.

Begitu juga dalam tradisi Barat, melamar lebih identik pada aktivitas yang dilakukan laki-laki terhadap perempuan. Sebagai contoh, di Amerika lamaran akan terjadi apabila seorang laki-laki menyampaikan maksudnya untuk mengikat hubungan lebih serius (melamar) terhadap perempuan, biasanya dengan kalimat "Will you marry me?" Sehingga aktivitas tersebut dinamakan melamar atau meminang. Dalam bahasa Inggris kata atau frase yang memiliki makna melamar adalah to betroth, to propose marriage dan to ask to marry. Kata to betroth mempunyai kesamaan arti (sinonim) dengan kata to engage, to affiance, to plight dan to vow.

\section{b. Aktivitas yang Secara Tradisional Biasa Dilakukan oleh Gender Tertentu}

Aktivitas yang secara tradisional biasa dilakukan oleh gender tertentu, maksudnya adalah aktivitas tersebut mengacu pada pekerjaan atau bidang kerja. Dalam kehidupan sehari-hari secara umum bidang kerja dibagi dua, yaitu bidang kerja tradisional dan non-tradisional. Awalnya pembagian bidang kerja seperti ini berdasarkan pada pemisahan tugas menurut perbedaan jenis kelamin. Bidang kerja tradisional didominasi oleh perempuan, sementara bidang kerja non-tradisional didominasi oleh laki-laki. ${ }^{25} \mathrm{Hal}$ ini dilakukan karena adanya perbedaan kekuatan fisik antara laki-laki dan perempuan. ${ }^{26}$ Pekerjaan yang memerlukan kekuatan fisik tinggi diserahkan kepada laki-laki dan digolongkan kepada pekerjaan non-tradisional. Pekerjaan-pekerjaan tersebut diwujudkankan dalam kegiatan yang secara

${ }^{25}$ Betz, N. E. \& Fitzgerald L. F. The Career Psychology of Women, (New York: Routledge Press, 2000). 2005).

${ }^{26}$ Basow. Sex-Role Stereotypes, Traditions and Alternatives, (Birmingham: University Press, 
tradisional bisa dilakukan perempuan dan yang secara non-tradisional bisa dilakukan laki-laki.

Pertama, aktivitas yang secara tradisional biasa dilakukan perempuan. Aktivitas dalam bidang kerja tradisional dideskripsikan sebagai kegiatan yang didominasi oleh perempuan. ${ }^{27}$ Sebagaimana yang pernah dinyatakan oleh Parson \& Bales $^{28}$ bahwa aktivitas yang dijalankan perempuan adalah aktivitas emosional atau ekspresif yang bertujuan menjaga keselarasan dan kerjasama dalam kelompok, misalnya aktivitas sebagai pemberi cinta, perhatian dan kasih sayang. Aktivitas tersebut membutuhkan kualitas feminin, emosional/ekspresif yang lebih dominan. Sebagai contoh, verba yang menunjukan aktivitas tersebut adalah to babysit, to childmild, to chaperone, to nurse.

Verba to babysit berarti mejaga seorang bayi atau anak biasanya dilakukan oleh seseorang sebagai kegiatan diluar rumah atau dilakukan di rumah mereka yang memiliki bayi atau anak tersebut. Verba yang bersinonim dengan to babysit adalah to take care, to sit (sebagai verba intransitif), to tend, dan to watch. Selanjutnya verba to chaperone berarti menemani (mengawal) seorang gadis atau anak yang dilakukan oleh perempuan. Kegiatan yang bersinonim dengan to chaperone adalah to accompany, to escort dan to guard.

Aktivitas-aktivitas yang dilakukan perempuan di atas merupakan gambaran stereotip yang ada di masyarakat yang berimbas pada pekerjaan. Sebagaimana yang ditegaskan oleh Novarra ${ }^{29}$ jika seorang perempuan harus bekerja, maka apa yang dikerjakannya di luar rumah tidak jauh dari perannya dalam rumah tangga. Bahkan di awal era kesetaraan gender, masih ada pendapat bahwa tabu hukumnya bagi kaum perempuan untuk bergerak di bidang politik atau bidang publik, jika perannya tidak sebangun dengan perannya dalam rumah tangga. Misalnya kegiatan yang terkait dengan pengasuhan anak (to babysit, to childmild, to take care, to sit, to tend, dan to watch), menjaga atau mengawal anak atau gadis (to chaperone, to accompany, to escort dan to guard), pengurusan rumah tangga (to cook, to serve, to service, to clean, to launder dan to iron), pembuatan pakaian (to sew, to stitch, to tailor, dan

\footnotetext{
${ }^{27}$ Betz, N. E. \& Fitzgerald L. F. The Career Psychology of Women.

${ }^{28}$ Megawangi R. Membiarkan Berbeda? Sudut Pandang Baru tentang Relasi Gender, (Jakarta: Yayasan Obor, 2006).

${ }^{29}$ Vianello, M. Gender Inequality. A Comparative Study of Discrimination and Participation, (Birmingham: University Press, 2005).
} 
to design), dan perawatan orang sakit dan cacat (to nurse). Perbedaannya adalah pada tempat kegiatan atau lokasi kerja tersebut, yaitu di luar rumah, dan dengan bekerja di luar rumah perempuan pekerja mendapat imbalan atas jasanya.

Kedua, aktivitas non-tradisional yang bisa dilakukan laki-laki. Aktivitas non-tradisional didefinisikan sebagai bidang kerja yang didominasi lakilaki ${ }^{30}$, sehingga peran yang dijalankan laki-laki adalah peran instrumental yang bertujuan mencapai kepentingan kelompoknya, misalnya peran sebagai pencari nafkah. ${ }^{31}$ Oleh karena itu, aktivitas non-tradisional merupakan aktivitas atau pekerjaan yang membutuhkan kualitas maskulin/ instrumental yang lebih dominan.

Aktivitas non-tradisional bisa dilakukan laki-laki dapat dilihat dari karakteristik pekerjaan tersebut yaitu memerlukan komitmen jangka panjang, diperlukan pengetahuan tertentu yang dapat digunakan untuk menjalankan tugas, sarat akan kompetisi, memiliki tujuan yang harus dicapai dalam jangka waktu tertentu, dan sebagainya. Contoh verba yang menunjukan aktivitas non-tradisional adalah to lead, to earn, to manage, to sail, to navigate, to supervise. Sebagai contoh, aktivitas dalam bidang kerja manajemen (to manage) dimana diperlukan pengetahuan dan skill tertentu untuk dapat menjalankan pekerjaan dengan baik, memiliki tujuan yang harus dicapai agar dapat mengembangkan usaha, dan seterusnya. Meskipun aktivitas tersebut bisa dilakukan oleh perempuan, namun kecenderungan aktivitas lebih dominan pada laki-laki. Selain itu, memberi nafkah pada istri atau keluarga (to earn), memimpin (to lead) dan sebagainya merupakan aktivitas yang memang lebih didominasi oleh kaum laki-laki.

\section{c. Aktivitas yang Dilakukan Gender Tertentu demi Gender Lain}

Aktivitas yang memang dilakukan gender tertentu demi gender lain maksudnya aktivitas tersebut dilakukan untuk membuat tertarik dan senang gender lain. Pertama, aktivitas yang memang dilakukan laki-laki demi perempuan, tercermin dalam verba to shave, to ponce about/around, to curtschat $s b$ up dan to win sb's affections. Verba to win sb's affections merupakan frasa verba yang berarti berhasil membujuk seseorang untuk mencintaimu. Cara

${ }^{30}$ Betz, N. E. \& Fitzgerald L. F. The Career Psychology of Women.

${ }^{31}$ Megawangi R. Membiarkan Berbeda? Sudut Pandang Baru tentang Relasi Gender. 
membujuk bisa dengan merayu, mengajak berkencan dan sebagainya. Kemudian to curtschat sb up yang berarti menunjukan tertarik pada seseorang dengan perkataan, misalnya dengan cara merayu atau memuji.

Kedua, aktivitas yang memang dilakukan perempuan demi laki-laki, tercermin dalam verba to sterilize, have a boob job, to doll yourself up, to come on, dan to curtsy/to curtsey. Beberapa upaya yang dilakukan perempuan untuk menjaga hubungannya dengan laki-laki atau menarik perhatian laki-laki diantaranya adalah to sterilize, to have a boob job, to doll yourself up, to come on (membuat ketertarikan seksual terhadap lawan jenis, sebagai contoh menggunakan baju ketat/rok mini), to curtsy / to curtsey (memberi hormat dengan cara menekuk lutut atau memperhalus tutur kata).

Verba to sterilize berarti upaya membuat mandul (memandulkan). Secara medis sterilize bisa dilakukan oleh perempuan, dengan cara pemotongan atau pengikatan saluran sel telur (tubectomy) dan laki-laki, dengan cara pembedahan untuk memandulkan laki-laki dengan pemotongan saluran sperma (vasectomy). Pada dasarnya melakukan sterilize bertujuan untuk mencegah kehamilan. Meskipun sterilize bisa dilakukan oleh perempuan maupun laki-laki, namun aktivitas ini lebih didominasi pada perempuan. Ada beberapa alasan kecenderungan sterilize dilakukan oleh perempuan yaitu perempuan lebih beresiko hamil, menjaga kecantikan dan kesehatan.

\section{d. Aktivitas yang Secara Kodrati Hanya Bisa Dilakukan Gender Tertentu}

Kata kodrat dalam arti kemampuan, kekuasaan atau sifat bawaan menunjukan adanya keterlibatan aktif dari si pelaku terhadap apa yang bisa dilakukannya sendiri. Tanpa bergantung/terkait dengan selain dirinya. Kata kodrat kemudian lebih bermakna kemampuan yang bersumber dari dalam individu untuk melakukan atau tidak melakukan sesuatu (free will \& free act). Sementara kata takdir dalam arti ketentuan/ketetapan menunjukan adanya sebuah garis kekuasaan harus tunduk patuh (bahkan tidak mampu mengelak dari) ketentuan yang berasal dari atas. Seperti pemberian alat kelamin pada manusia oleh Tuhan yang menentukan seseorang secara biologis lakilaki dan perempuan tanpa bisa ditawar. ${ }^{32}$

${ }^{32}$ Lihat Nasaruddin Umar, "Perspektif Gender dalam Islam". 
Verba yang menunjukan aktivitas kodrati sebagai berikut. Pertama, aktivitas yang secara kodrati dilakukan laki-laki, misalnya to ejaculate (ejakulasi). Ejakulasi hanya terjadi pada laki-laki. ${ }^{33}$

Kedua, aktivitas yang secara kodrati dilakukan perempuan. Pada dasarnya kodrat bukan sesuatu yang di dasarkan faktor biologis. Kodrat bukan pula sesuatu yang terberi begitu saja dari Allah (given) yang harus dilakukan dan tak ada seorang pun yang bisa menghindarinya. Tetapi ada manusia (subjek) dan unsur-unsur budaya yang membentuknya. Kodrat perempuan pada akhirnya sarat dengan muatan-muatan lokal. Aktivitas tersebut membawa implikasi sosial maupun budaya. Sebagai contoh aktivitas to carry (mengandung), perempuan yang mengandung membawa perubahan pada fisiologisnya seperti big, enceinte, expectant, gravid, great, large, heavy, with child, yang secara sosial ada perbedaan bentuk tubuh antara orang yang mengandung (hamil) dengan yang tidak hamil. Selain di atas, kodrat perempuan lainnya adalah melahirkan, menyusui dan menstruasi. Dalam bahasa Inggris istilah-istilah tersebut yang terdapat dalam kamus adalah mengandung (to carry, to be expecting (baby); melahirkan (to foal, to deliver, to give birth, to breed (istilah ini digunakan untuk binatang/animal); menyusui (to suckle, to breast feed) dan mensturasi (to mensturate).

\section{e. Aktivitas yang Mendeskreditkan atau Bermakna Negatif pada Gender Tertentu}

Aktivitas yang mendeskreditkan atau bermakna negatif pada gender tertentu maksudnya aktivitas tersebut digunakan untuk mendeskreditkan seseorang atau memiliki makna negatif bagi orang tersebut baik pada lakilaki maupun perempuan. Aktivitas tersebut dibagi, pertama, aktivitas yang mendeskreditkan atau bermakna negatif pada laki-laki. Verba tersebut adalah to womanize, to emasculate, to defrock, to castrate, dan to dally with sb (also dally with sb's affections). Sebagai contoh, verba to defrock. Kata to defrock

\footnotetext{
${ }^{33}$ Pada saat ejakulasi yang terjadi adalah keluarnya air mani yang di dalamnya terkandung banyak sperma. Jumlahnya bisa ratusan juta pada laki-laki yang sehat, sehingga bisa menyebabkan kehamilan pada perempuan. Secara fisiologis, laki-laki ditakdirkan memiliki sperma di dalam tubuh yang diproduksi minimal dalam waktu tiga hari. Proses pengeluaran air mani ini disebut ejakulasi. Sehingga, hanya laki-laki yang bisa melakukan kegiatan ini.
} 
memiliki beberapa arti, yaitu menghapus fungsi dan hak istimewa imam/ pendeta; mencabut hak untuk berlatih profesi dan mencabut dari posisi kehormatan. Verba to defrock bersinonim dengan to impeach, dengan istilah umum yang lebih dikenal dalam nomina impeachment, yang berarti pemakzulan. Impeachment merupakan sebuah proses dari sebuah badan legislatif yang secara resmi menjatuhkan dakwaan terhadap seorang pejabat tinggi negara. Pemakzulan bukan selalu berarti pemecatan atau pelepasan jabatan, tetapi hanya merupakan pernyataan dakwaan secara resmi, mirip pendakwaan dalam kasus-kasus kriminal, sehingga hanya merupakan langkah pertama menuju kemungkinan pemecatan. Saat pejabat tersebut telah dimakzulkan, ia harus menghadapi kemungkinan dinyatakan bersalah melalui sebuah pemungutan suara legislatif, yang kemudian menyebabkan kejatuhan. Meskipun bukan berarti pemecatan atau pelepasan jabatan tetapi makna ini mendeskreditkan seseorang karena ada upaya menjatuhkan kredebilitas seseorang yang sedang menjabat dengan cara pemberian pernyatan dakwaan. Jabatan atau posisi pekerjaan mempunyai periodisasi pergantian, namun penggunan to defrock maupun to impeach merupakan pergantian jabatan atau posisi pekerjaan tertentu yang terjadi akibat pejabat atau pekerja tersebut melakukan sesuatu kesalahan atau sesuatu yang dianggap buruk, sehingga pergantian tersebut bermakna negatif. Contoh kalimat yang menggunakan verba defrock adalah:

It is time to have an Anglican pope with all the powers to defrock and expel the heretical bishops in the Canadian and American churches. ${ }^{34}$

Kedua, verba yang mendeskreditkan atau bermakna negatif pada perempuan misalnya to prostitute dan to abort. Verba to abort, secara singkat berarti menggugurkan (kandungan atau bayi), maksudnya menghentikan perkembangan bayi yang belum lahir, biasanya dengan memiliki operasi medis. Makna mengaborsi lebih mengarah kepada suatu tindakan yang disengaja untuk mengakhiri kehamilan seorang ibu ketika janin sudah ada tandatanda kehidupan dalam rahim. Istilah abort (aborsi) dan abortus (abortus) sering digunakan secara bergantian walaupun sesungguhnya ada perbedaan dari keduanya. Makna abortus sendiri lebih menjelaskan kepada proses terpencarnya embrio (cikal bakal janin) sehingga tidak memungkin-kan lagi

${ }^{34}$ www.freedictionary.com 
hidup, sering juga disebut keguguran, atau terhentinya per-tumbuhan yang normal. Pada kenyataannya orang lebih sering mengguna-kan kata abortus dalam arti keguguran (pengguguran kandungan).

Abortus sendiri terbagi dua yaitu abortus spontan dan abortus provocatus. Abortus spontan sering disebut dengan keguguran. Sedangkan abortus provocatus sendiri terbagi menjadi dua. Pertama, abortus provocatus artificial adalah pengguguran kandungan menggunakan alat-alat medis dengan alasan kehamilan membahayakan dan dapat membawa maut bagi ibu, misalnya karena ibu berpenyakit berat tertentu.

Tindakan abortus ini lebih sering disebut abortus terapeutik, diizinkan menurut ketentuan profesional seorang dokter untuk menyelamatkan ibu yang mengandung. Kedua, abortus provocatus criminalis adalah pengguguran kandungan tanpa alasan medis yang sah dan dilarang oleh hukum. Termasuk dalam abortus jenis ini adalah abortus yang terjadi atas permintaan pihak perempuan kepada seorang dokter untuk menggugurkan kandungannya.

Menurut pengertian tersebut di atas, makna kata to abort belakangan ini lebih cenderung pada istilah abortus provocatus criminalis, yaitu menggugurkan kandungan tanpa alasan medis yang sah. Tindakan abort (aborsi), kecuali aborstus terapeutik adalah melanggar hukum dan tidak dapat dibenarkan demi hukum apapun juga rasionalisasinya. Sehingga makna verba to abort akan menjadi negatif bagi yang melakukan (perempuan). Contoh kalimat yang menggunakan kata to abort bermakna negatif:

But we say don't abort girls because they also have future, give them school and they will have good job, "said Niskata, another foreigner participant..$^{35}$

\section{Penutup}

Seringnya Islam dibahas dan dikaji sebagai sumber bias gender oleh pihak Barat ternyata tidak disertai kajian serupa terhadap budaya Barat oleh masyarakat Timur dengan asumsi Barat adalah penggerak kesetaraan. Akan tetapi, dengan melihat bahasa sebagai cerminan sebuah budaya, peneliti berusaha melakukan kajian terhadap budaya Barat yang diwakili oleh

\footnotetext{
${ }^{35}$ Diambil dari "Thousands of Girls Take to Streets Protesting Against Abortions" dalam Surat Kabar Asian News International.
} 
budaya penutur berbahasa Inggris sebagai bahasa yang dianggap paling banyak digunakan di dunia ini. Dengan kata lain, bahasa Inggris sebagai salah satu bahasa 'terbesar' yang mewakili Barat akan menunjukkan bagaimana gender diposisikan di dalam budaya tersebut .

Dasar tulisan ini sendiri adalah sebuah hipotesis fenomenal dari SapirWhorf, yaitu teori relativitas bahasa, yang menyatakan bahwa bahasa mempengaruhi budaya. Oleh karena itu, untuk melihat apa yang terjadi pada sebuah budaya, dapat dilihat dari struktur bahasa (baik struktur gramatika juga leksikon). Dengan sebuah alasan bahwa struktur makna yang biasanya diwakili leksikon atau kosakata secara rasional memiliki keterkaitan erat mengingat jika sebuah kata telah diakui keberadaannya dalam sebuah bahasa, tentunya hal tersebut telah cukup mengemuka dalam budaya penuturnya, sehingga penamaannya secara leksikal dianggap penting daripada sekedar membicarakan hal tersebut dengan strategi gramatika.[]

\section{Daftar Pustaka}

Aryani, Sekarayu, Pengarusutamaan Gender dalam Kurikulum IAIN, Yogyakarta: PSW- IAIN Press, 2004.

Baraimah, C., An analysis of English Textbooks in Nigeria. Florida: University Press, 2003.

Basow. Sex-Role Stereotypes, Traditions and Alternatives, Birmingham: University Press, 2005.

Betz, N. E. \& Fitzgerald L. F. The Career Psychology of Women, Newyork: Routledge Press, 2000.

Cooke-Sawyer,S., Gender Bias and Sex Role Stereorypes in Grade Seven History Textbooks, Toronto: Mc Gill University Press, 2000.

Crystal, The Cambridge Encylopedia of Language, Birmingham: Cambrige University Press, 1989.

Electronic Cambridge Advanced Learner's Dictionary $(C A L D) .3^{\text {rd }} \mathrm{Ed}$.

Gunawan, "Leksikon Bias Gender Bahasa Arab" dalam Jurnal Adabiyyat, vol. 4, 2005. 
Leech, Semantics, New Rochdale: University Press, 1998.

Liew Peok Chong. An analysys of Gender and Ethnic Representations in Chinese and Malay Primary School Reading Textbooks Grade 2-6. Birmingham: University Press, 2005.

Maiese, "Principles of Justice and Fairness." http://www.beyondintractability. org/bi-essay/principles-of-justice, diunduh 17 November 2014.

Mazile P. The Portrayal of Women in Botswana's Social Studies and History Textbooks. Birmingham: University Press, 2005.

Megawangi R. Membiarkan Berbeda? Sudut Pandang Baru tentang Relasi Gender, Jakarta: Yayasan Obor, 2006.

Mukminatien, "Hubungan antara Bahasa dan Gender serta Implikasinya dalam Pembelajaran Writing", Pengukuhan Guru Besar pada tanggal 6 Mei 2010 di Universitas Negeri Malang.

al-Qadhi Abd al-Jabbar, Ushul al-Khamsah, Juz 2, al-Qahirah: Dar al-Kutub alArabiyah, $1324 \mathrm{H}$.

Ryf, J. English Language Textbooks in Zimbabwe: A Gender Analysis, Melborn: Monash University, 2006.

Saussure, De, Course in General Linguistics, London: Cambrige, 2000.

Subhan, "Gender dalam Perspektif Islam", dalam Jurnal Akademika, Vol. 06, No. 2, Maret 2004.

Sydney, Gameliel Valentino Mkucu, Gender Roles in Textbook as Function of Hidden Curriculum in Tanzania Primary School, Toronto: Mc Gill University Press, 2000.

Thousands of Girls Take to Streets Protesting Against Abortions dalam Surat Kabar Asian News International.

Tim Penyusun, Ensiklopedi Nasional Indonesia, cet. III, Jakarta: Balai Pustaka, 1995.

Ulmann, Semantics: An Introduction to the Science of Meaning, Philadelpia: Pitts University. 1999.

Umar, Nasaruddin, "Perspektif Gender dalam Islam", Jurnal Paramadina, Vol. I. No. 1, Juli-Desember 1998.

Vianello, M. Gender Inequality. A Comparative Study of Discrimination and Participation, Birmingham: University Press, 2005. 